\title{
Reseña. Héctor Tobar, The Barbarian Nurseries. New York: Farrar, Straus and Giroux, 2011.
}

The United States, a nation of immigrants, has long enticed outsiders with the allure of work and educational opportunities they were unable to find at home. Latin Americans constitute the largest diaspora residing in the country, and it is Mexicans who have grown into the principal Latino population group. Each year scores of irregular migrants join them, prepared to carry out menial, low-paid jobs in order to eventually fulfill their dreams of a better life. In his second novel, Los Angeles Times journalist and Pulitzer Prize winner, Héctor Tobar, bases his narrative in the experiences of undocumented Mexican settlers in cosmopolitan yet racially divided California, while reflecting upon larger themes connected with U.S. immigration policy. Born in the state capital to Guatemalan parents, Tobar is ideally poised to chronicle the human drama associated with one of the most intricate socio-cultural and political issues of our times.

Set in contemporary Southern California, the story revolves around Araceli Ramírez, an undocumented migrant from Mexico City who works as a live-in maid in the affluent and liberal household of Scott Torres and Maureen Thompson. The financially-troubled couple let go of their nanny and gardener, requiring Araceli to look after their three children. After a bitter argument Scott and Maureen storm separately out of the house, leaving behind their two sons. Running out of food and unsure what to do, Araceli decides to take the boys to their Mexican-born grandfather, whom she knows only from a photo and believes lives in central Los Angeles. Araceli, however, fails to locate the grandfather, and the three of them are forced to stay with friends of hers. Meanwhile, Scott and Maureen return to an empty home and report their sons kidnapped. Araceli is 
detained and put before the courts, but pro-immigrant groups help her - successfully - to fight her deportation. Following this eye-opening experience, Araceli joins Felipe the gardener to embark on a new phase of her life, though the reader is left not knowing whether this journey will take her elsewhere in the United States or back to Mexico. The story, spanning not more than a few days and told through flashbacks, is permeated by three themes: immigration, race and class. Araceli, the narrative's central character, comes across as a complex character whose trajectory is quite unlike that of the typical doméstica. A former art student who had to abandon her schooling for financial reasons, she subverts the stereotype of the undocumented migrant as poorly educated. Though often tight-lipped and not keen on having the role of the nanny forced upon her, she displays great sensitivity when faced with the dilemma of what to do with the boys. The massive search operation for Araceli and the children, the media frenzy surrounding it, and girl's travails with the California judicial system unfold in the context of the debate around U.S. immigration policy. Although California, like much of the nation, subscribes to the idea of the melting pot, it does not treat new arrivals kindly. Foreign-born residents contribute in large measure to the economy and often perform tasks that native citizens reject, yet they maintain a largely invisible presence. Indeed, the novel's title subtly refers to two of the jobs that Mexican immigrants often perform: raising children or raising plants (either as gardeners or agricultural workers).

wAs the story develops, Tobar illustrates how wealthy individuals are perfectly happy to entrust strangers with a variety of chores, but show little interest in getting to know them or their reasons for venturing - often in perilous circumstances - into foreign lands. On the one hand, the writer reveals how immigrants may experience cultural alienation and reproduce traditions they had to leave behind, but remember with nostalgia, such as the quinceañera celebration that Araceli's friends invite her to attend. On the other hand, Latinos' growing cultural influence causes unease among some sections of the U.S. population which, beholden to a sensationalist media and unfamiliar with Hispanic languages 
and customs, view undocumented migrants with suspicion. The protesters who gather at Araceli's hearing symbolize the divisions in opinion, but with his depiction of the sole anti-immigration activist Tobar wants to sound a hopeful note that the country may one day see a policy turnaround. Araceli, for her part, is left transformed by the social and legal odyssey she goes through and ultimately feels that she can no longer go back to who she was. Here, the author ably conveys how immigrants can build a life for themselves in their host country without abandoning their roots, even if their relations with family back home remain underexplored in the novel.

The issue of race is considered through the eyes of Scott, but more often through the gaze of the Latinos he and his wife hire to perform household errands or odd jobs. The thread running through their lives is the intimate connection between physical appearance and social position. Scott, a second-generation Mexican-American, is in denial of his Latino heritage and would rather be seen as a wealthy programmer. His father, whom Tobar affectionately refers to as el abuelo Torres, came to California many decades earlier. The elderly man is conspicuously absent from the couple's home, where a photo is the only reminder of him. It is only when the charges against Araceli have been dropped and a degree of normalcy returns to the Torres-Thompson home that he temporarily moves in with his relatives and helps them with their chores. Although developments suggest that Scott may come to embrace his Hispanic identity, the author does not develop the relationship between father and son.

The Mexican immigrants that populate the narrative inspire Tobar to mull over the stereotypes and prejudices that are readily tied to mestizo skin. The starting-point is the discourse infusing U.S. public life that refers to Mexico as an uncivilized country, and a place rife with violence and unskilled workers. Given their origins and legal status, undocumented Hispanic migrants are - in certain quarters of society - associated with illegality and barbarism. This image fuels fears about the citizens of developing nations and is expressed both metaphorically and through rhetorical devices, in the title and throughout the 
novel. The idea emerges with particular resonance when the Mexican gardeners chop down Maureen's dying tropical rain forest with their machetes or when a bystander wonders why important responsibilities such as child care are assigned to Mexican immigrants. Consequently, race is intimately bound up with class and the constraints both of these categories place on people's choices and decisions.

Tobar's chief concern lies with the social disparities that characterize Southern California. Having been brought up in modest circumstances, Scott and Maureen's backgrounds are not entirely dissimilar from that of Araceli. Yet, while they inhabit the same household, they remain worlds apart. The couple own a large house with an ocean view and, wanting only the best for their children, spoil them with books and toys, but not shared time. Their lives, empty and unfulfilled, are largely about keeping up appearances. In the portrayal of the indebted Torres-Thompson home, nothing exemplifies their consumer lifestyle better than Maureen's obsession with her tropical rainforest and its costly replacement with a newly succulent garden.

The contrast with this idyllic setting occurs when Araceli and the boys travel from the gated communities of Orange County to the impoverished immigrant barrios of central Los Angeles. From the reader's point of view, this voyage into urban landscapes of neglect, decay and poverty is as saddening as it is amusing. As the mosaic of industrial areas, working class districts and homeless encampments unfolds, the hitherto insulated children need to compare the scenes before them with those from well-known adventure books in order to make sense of them. Tobar not only uncovers the many layers of history woven into the various neighborhoods, but also relates how people, despite their ethnic differences, are united by the desire to get ahead. In this blue-collar Los Angeles, commonly sidelined by literary depictions of Hollywood glamour, the author brings to life a sense of community, deeply caring individuals, proletarian intellectuals and - above all - human beings who endeavor to transcend the limitations of their origins. The journey here is not just one between distinct 
spaces, but also one between distinct cultures and values, between populations that live side by side, yet know little of each other.

The Barbarian Nurseries is a dense and beautifully written novel that renders a powerful portrayal of a wide-ranging cast. At times the work seems unnecessarily detailed, for example when the Torres-Thompson household and its lavish spending habits are described with almost obsessive precision; however, Tobar proves himself to be a perceptive observer of social reality, displaying a brilliant mastery of the subject matter and resourcefully evoking the different atmospheres of both Los Angeles and Mexico City. By slipping under the skin of his characters and relating their personal struggles for happiness and selffulfillment, above all the author makes undocumented migrants visible and humanizes them. The work will appeal to anyone interested in contemporary social issues in the United States, but it is also suited for classroom adaptation, especially in the field of Latin American and Latino Studies. While its chief educational aspect lies in bringing readers closer to the Latino immigrant experience, the novel invites a broader reflection upon more effective state responses to the reality of undocumented migrants, especially for young people who have spent much, if not all, of their life in the United States.

\section{(oc) EY-NC-ND}

ULIS D-Sork
This work is licensed under a Creative Commons Attribution-Noncommercial-No Derivative Works 3.0 United States License.

This site is published by the University Library System, University of Pittsburgh as part of its D-Scribe Digital Publishing Program and is cosponsored by the University of Pittsburgh Press. 